\title{
Esterification of Mixed Carboxylic-fatty Anhydrides Using Amberlyst-15 as Heterogeneous Catalyst
}

\author{
Iteb Trabelsi, Kamel Essid* and Mohamed Hedi Frikha \\ Laboratory of Physical and Organic Chemistry: Department of Chemistry, Faculty of Sciences in Sfax, TUNISIA
}

\begin{abstract}
The article deals with the use of mixed anhydrides for the synthesis of fatty esters. Both aliphatic and aromatic acids are involved, indicating different behaviors according to the chain length of the aliphatic acid. We describe a novel and efficient method for the synthesis of fatty esters by the esterification reaction of primary, secondary and tertiary alcohols with mixed carboxylic-palmitic anhydrides using resin Amberlyst-15 as heterogeneous acid catalyst. Influence of various reaction parameters such as molar ratio (anhydride/alcohol), catalyst amount, type of alcohol and type of mixed anhydride were studied to optimize the conditions for maximum yield. Among tested anhydrides we quote mainly the 4-chlorobenzoic palmitic anhydride because it was both reactive and selective for the preparation of palmitic acid ester. This anhydride gave a good yield of palmitic ester.
\end{abstract}

Key words: fatty acid, mixed anhydride, heterogeneous acid catalyst, resin Amberlyst-15, esterification

\section{Introduction}

The esterification of fatty acid with alcohol under acid catalyst is a reversible reaction limited by the low equilibrium conversion and slow reaction rate ${ }^{1)}$. To perform highyielding esterification with equimolar reaction of carboxylic acid and alcohol under mild conditions, activated derivatives of carboxylic acids (carboxylic acid chlorides or anhydrides) have been often employed ${ }^{2-4)}$. Carboxylic anhydrides in organic chemistry are acylating agents appreciated for their high reactivity compared to carboxylic acids ${ }^{5}$. They are also important classes of chemicals that have been used extensively as synthetic intermediates in the preparation of variety of fine or special chemicals such as amides, esters, peptides, drugs, etc. ${ }^{6}$. . Mixed anhydrides obtained from two different carboxylic acids are molecules finding an increasing interest in the chemical industry due to their high reactivity resulting from the difference in $\mathrm{pK}$ values of the two moieties in asymmetric molecules ${ }^{7,8)}$.

The aim of this work is the synthesis of fatty esters from mixed carboxylic fatty anhydrides using heterogeneous acid catalyst. They constitute an important class of useful chemical intermediates in the synthesis of several products $^{9-11)}$. These compounds are essential chemicals that are widely used in food, pharmaceutical, cosmetic, detergent, plasticizer, lubricant, textile and other industrial applications ${ }^{10-14)}$.

In a previous work we have prepared mixed carboxylic fatty anhydrides in organic solvent and in the presence of triethylamine as acid acceptor ${ }^{15)}$. These mixed anhydrides were prepared from palmitic acid and aliphatic or aromatic carboxylic acid chloride. This work describes a novel and efficient method of synthesis of fatty esters by esterification of mixed carboxylic fatty anhydrides using heterogeneous acid catalyst. We have investigated the reactivity of some carboxylic palmitic anhydrides in the esterification reaction of primary, secondary and tertiary alcohols and in the presence of resin Amberlyst-15. We have optimized the conditions for maximum esterification yields by varying different reaction parameters such as molar ratio (anhydride/alcohol), effect of catalyst amount and type of alcohol.

\section{Experimental}

\subsection{Chemicals}

The chemicals purchased from Sigma-Aldrich Company include: Palmitic acid (90\%), benzoyl chloride ( $\geq 99 \%)$, 4-chlorobenzoyl chloride (99\%), pivaloyl chloride(99\%), acetyl chloride (98\%), 2-phenylethanol (99\%), benzyl alcohol (99.8\%) , 2-butanol (99\%), 2-methyl-2-propanol $(99.5 \%)$, salicylic acid (99\%), triethylamine ( $\geq 99.5 \%)$, hexane $(\geq 95 \%)$, dichloromethane $(99.8 \%)$.

Amberlyst-15 was purchased from Fluka and used as re-

*Correspondence to: Kamel Essid, Laboratory of Physical and Organic Chemistry: Department of Chemistry, Faculty of Sciences in Sfax, TUNISIA

E-mail: kamelessid.issat@yahoo.fr

Accepted March 10, 2017 (received for review January 13, 2017)

Journal of Oleo Science ISSN 1345-8957 print / ISSN 1347-3352 online

http://www.jstage.jst.go.jp/browse/jos/ http://mc.manusriptcentral.com/jjocs 


\section{Trabelsi, K. Essid and M. H. Frikha}

ceived. It is brown-grey solid having the following physical properties: ionic form: hydrogen, matrix: styrene-divinylbenzene, particle size: $<300 \mu \mathrm{m}$, maximum operating temperature: $120^{\circ} \mathrm{C}$, exchange capacity: $4.7 \mathrm{meq} / \mathrm{g}$.

\subsection{Preparation of mixed carboxylic-palmitic anhydride}

Mixed anhydrides were prepared by reaction between palmitic acid as fatty acid, acid chloride (such as acetyl chloride, pivaloyl chloride, benzoyl chloride and 4-chlorobenzoyl chloride) and triethylamine with the molar ratios 1:1.1:1.1. The reaction proceeded at room temperature for three hours in hexane $(50 \mathrm{~mL})$. The obtained crude anhydrides were used in the esterification reaction with different alcohols.

These crude mixed anhydrides were employed directly in the esterification reaction. Their composition was determined by ${ }^{1} \mathrm{H}$ NMR and resumed in Table 1.

\subsection{Esterification of alcohols by mixed carboxylic-palmitic anhydrides}

The esterification reactions of primary, secondary and tertiary alcohols with crude anhydrides mixtures, were performed in hexane as solvent $(25 \mathrm{~mL})$ in the presence of an ion-exchange resin (Amberlyst-15). The esterification reactions were refluxed with stirring for 4 hours. Different initial molar ratios between crude anhydrides and alcohols were employed (1:1, 1:2 and 1:4). The influence of amount in Amberlyst-15 cation resin (exchange capacity: 4.7 meq/ g) was investigated. When the reaction was completed, the reaction mixture was filtered and the Amberlyst-15 washed with hexane $(20 \mathrm{~mL})$. The solvent was then evaporated to dryness and the crude product was weighed and analysed by IR, ${ }^{1} \mathrm{H}$ NMR and ${ }^{13} \mathrm{C}$ NMR spectroscopy (Table 2 ).

\subsection{Spectroscopic analysis}

The IR analysis was performed using a spectrometer type Perkin Elmer Spectrum version 10 in a wave number range of 500-4000 $\mathrm{cm}^{-1}$. The ${ }^{1} \mathrm{H}$ NMR and ${ }^{13} \mathrm{C}$ NMR spectra were carried out at $25^{\circ} \mathrm{C}$ on a Bruker Avance III HD at a ${ }^{1} \mathrm{H}$ frequency of $400 \mathrm{MHz}$ and ${ }^{13} \mathrm{C}$ frequency of $100 \mathrm{MHz}$. Each sample was dissolved in $\mathrm{CDCl}_{3}$ or in mixture of $\left(\mathrm{CDCl}_{3} /\right.$ DMSO).

The ${ }^{1} \mathrm{H}$ NMR spectral data of the crude product obtained by the esterification of 2 phenhyl- ethanol with 4-chlorobenzoic palmitic anhydride (Table 3 entry 2), taken as representative example, are summarized below.

\section{1: 2-phenylethyl palmitate}

${ }^{1} \mathrm{H} \mathrm{NMR}\left(400 \mathrm{MHz}, \mathrm{CDCl}_{3}\right.$ and DMSO $) \delta 0.83\left(\mathrm{t}, 3 \mathrm{H}, \mathrm{CH}_{3}^{-}\right)$, $1.20\left(\mathrm{~m}, 24 \mathrm{H},-\mathrm{C}_{12} \underline{\mathrm{H}}_{24}{ }^{-} \mathrm{C}_{2} \mathrm{H}_{4} \mathrm{CO}-\mathrm{O}-\right)$, 1.46-1.49 (m, $2 \mathrm{H},-\mathrm{CH}_{2}{ }^{-}$ $\left.\mathrm{CH}_{2} \mathrm{CO}-\mathrm{O}-\right), 2.19\left(\mathrm{t}, 2 \mathrm{H},-\mathrm{CH}_{2}-\mathrm{CO}-\mathrm{O}-\right), 2.85$ (t, $2 \mathrm{H},-\mathrm{CH}_{2}-$ $\mathrm{CH}_{2}-\mathrm{O}-$ ) , 4.18 (t, $2 \mathrm{H},-\mathrm{CH}_{2}-\mathrm{O}-$ ) , 7.14-7.25 ( m, 5H, Ar-H).

2: 4-chlorobenzoic acid

${ }^{1} \mathrm{H} \mathrm{NMR}\left(400 \mathrm{MHz}, \mathrm{CDCl}_{3}\right.$ and DMSO) $\delta 7.42(\mathrm{~d}, \mathrm{~J}=8.4$ $\mathrm{Hz}, 2 \mathrm{H}, \mathrm{Ar}-\mathrm{H}), 7.91$ (d, J=8.4 Hz, 2H, Ar-H).

3: 2-phenylethyl 4-chlorobenzoate

${ }^{1} \mathrm{H} \mathrm{NMR}\left(400 \mathrm{MHz}, \mathrm{CDCl}_{3}\right.$ and $\left.\mathrm{DMSO}\right) \delta 3.01\left(\mathrm{t}, 2 \mathrm{H},-\mathrm{CH}_{2}-\right.$ $\mathrm{CH}_{2}-\mathrm{O}-$ ), 4.43 (t, 2H, - $\mathrm{CH}_{2}-\mathrm{O}-$ ), 7.14-7.25 ( m, 5H, Ar-H) . $7.40(\mathrm{~d}, \mathrm{~J}=8.4 \mathrm{~Hz}, 2 \mathrm{H}, \mathrm{Ar}-\mathrm{H}), 7.88(\mathrm{~d}, \mathrm{~J}=8.4 \mathrm{~Hz}, 2 \mathrm{H}, \mathrm{Ar}-\mathrm{H})$.

\section{Results and discussion}

\subsection{Esterification of primary and secondary alcohols with} crude mixed anhydrides

Mixed anhydrides used in this study were freshly prepared by the action of palmitic acid on aromatic or aliphatic acid chlorides as indicated in Scheme $1^{15)}$.

Table 1 Composition of crude mixture anhydride.

\begin{tabular}{|c|c|c|}
\hline Entry & Crude mixed anhydride & $\begin{array}{l}\text { Composition of crude mixture } \\
\text { anhydride }\end{array}$ \\
\hline \multirow[t]{3}{*}{1} & Benzoic-Palmitic & $50.50 \%$ : benzoic palmitic anhydride \\
\hline & & $24.24 \%$ : palmitic anhydride \\
\hline & & $25.25 \%$ : benzoic anhydride \\
\hline \multirow[t]{3}{*}{2} & 4-Cl-benzoic-Palmitic & 73\%: 4-Cl-benzoic palmitic anhydride \\
\hline & & 19.6\%: palmitic anhydride \\
\hline & & 7.4\%: 4-Cl-benzoic anhydride \\
\hline \multirow[t]{3}{*}{3} & Palmitic-Pivalic & $51 \%$ : palmitic pivalic anhydride \\
\hline & & $22 \%$ : palmitic anhydride \\
\hline & & $27 \%$ : pivalic anhydride \\
\hline \multirow[t]{3}{*}{4} & Acetic-Palmitic & $84 \%$ : acetic palmitic anhydride \\
\hline & & $13 \%$ : palmitic anhydride \\
\hline & & $3 \%$ : acetic anhydride \\
\hline
\end{tabular}

\footnotetext{
${ }^{\text {a }}$ Composition of crude mixture anhydride determined by ${ }^{1} \mathrm{H}$ NMR.
} 
Table 2 Esterification of primary and secondary alcohols with crude mixed anhydride.

\begin{tabular}{|c|c|c|c|c|c|}
\hline Entry $^{a}$ & $\begin{array}{c}\text { Crude } \\
\text { mixed } \\
\text { anhydride }\end{array}$ & Alcohol & $\begin{array}{c}\mathrm{IR} \\
\left(\mathrm{C}=\mathrm{O}, \mathrm{cm}^{-1}\right)\end{array}$ & ${ }^{13} \mathrm{C}$ NMR $(\mathrm{C}=\mathrm{O}, \mathrm{ppm})$ & Crude mixture composition ${ }^{\mathrm{b}}$ \\
\hline 1 & $\begin{array}{l}\text { Benzoic- } \\
\text { Palmitic }\end{array}$ & $\begin{array}{l}\text { 2-Phenyl- } \\
\text { ethanol }\end{array}$ & $\begin{array}{l}\text { 1697: acid } \\
\text { 1727: ester }\end{array}$ & $\begin{array}{l}\text { 180.47: palmitic acid } \\
\text { 172.19: benzoic acid } \\
\text { 173.95: } 2 \text {-phenylethyl palmitate } \\
\text { 166.61: } 2 \text {-phenylethyl benzoate }\end{array}$ & $\begin{array}{l}\text { 9.16\%: palmitic acid } \\
\text { 26.40\%: benzoic acid } \\
49.70 \%: 2 \text {-phenylethyl palmitate } \\
14.74 \% \text { : 2-phenylethyl benzoate }\end{array}$ \\
\hline 2 & & Benzyl & $\begin{array}{l}\text { 1687: acid } \\
\text { 1730: ester }\end{array}$ & $\begin{array}{l}\text { 180.77: palmitic acid } \\
\text { 172.44: benzoic acid } \\
\text { 173.90: benzyl palmitate }\end{array}$ & $\begin{array}{l}\text { 50\%: palmitic acid } \\
42 \% \text { : benzoic acid } \\
8 \% \text { : benzyl palmitate }\end{array}$ \\
\hline 3 & & 2-Butanol & $\begin{array}{l}\text { 1686: acid } \\
\text { 1733:ester }\end{array}$ & $\begin{array}{l}\text { 180.36: palmitic acid } \\
\text { 172.15: benzoic acid } \\
\text { 173.72: } 2 \text {-butyl palmitate }\end{array}$ & $\begin{array}{l}48 \%: \text { palmitic acid } \\
42 \%: \text { benzoic acid } \\
\text { 10\%: } 2 \text {-butyl palmitate }\end{array}$ \\
\hline 4 & $\begin{array}{l}\text { 4-Cl- } \\
\text { benzoic- } \\
\text { Palmitic }\end{array}$ & $\begin{array}{l}\text { 2-Phenyl- } \\
\text { ethanol }\end{array}$ & $\begin{array}{l}\text { 1697: acid } \\
\text { 1729:ester }\end{array}$ & $\begin{array}{l}\text { 166.94: 4-Cl-benzoic acid } \\
\text { 173.13: 2-phenylethyl palmitate }\end{array}$ & $\begin{array}{l}\text { 45\%: 4-Cl-benzoic acid } \\
52 \%: 2 \text {-phenylethyl palmitate } \\
\text { 3\%: 2-phenylethyl 4-Cl-benzoate }\end{array}$ \\
\hline 5 & & Benzyl & $\begin{array}{l}\text { 1695: acid } \\
\text { 1733: ester }\end{array}$ & $\begin{array}{l}\text { 175.84: palmitic acid } \\
\text { 167.38: 4-Cl-benzoic acid } \\
\text { 173.43: benzyl palmitate }\end{array}$ & $\begin{array}{l}\text { 44\%: palmitic acid } \\
40 \%: 4-\text {-Cl-benzoic acid } \\
\text { 16\%: benzyl palmitate }\end{array}$ \\
\hline 6 & & 2-Butanol & $\begin{array}{l}\text { 1689: acid } \\
\text { 1733: ester }\end{array}$ & $\begin{array}{l}\text { 175.45: palmitic acid } \\
\text { 167.04: 4-Cl-benzoic acid } \\
\text { 173.03: 2-butyl palmitate }\end{array}$ & $\begin{array}{l}\text { 45\%: palmitic acid } \\
\text { 41\%: 4-Cl-benzoic acid } \\
\text { 14\%: 2-butyl palmitate }\end{array}$ \\
\hline $7^{\mathrm{c}}$ & & & $\begin{array}{l}\text { 1695: acid } \\
\text { 1731: ester }\end{array}$ & $\begin{array}{l}\text { 175.81: palmitic acid } \\
\text { 167.37: 4-Cl-benzoic acid } \\
\text { 173.34: 2-butyl palmitate }\end{array}$ & $\begin{array}{l}\text { 32\%: palmitic acid } \\
\text { 37\%: 4-Cl-benzoic acid } \\
\text { 31\%: 2-butyl palmitate }\end{array}$ \\
\hline 8 & $\begin{array}{l}\text { Palmitic- } \\
\text { Pivalic }\end{array}$ & $\begin{array}{l}\text { 2-Phenyl- } \\
\text { ethanol }\end{array}$ & $\begin{array}{l}\text { 1700: acid } \\
\text { 1735: ester }\end{array}$ & $\begin{array}{l}\text { 179.87: palmitic acid } \\
\text { 184.97: pivalic acid } \\
\text { 173.96: 2-phenylethyl palmitate } \\
\text { 178.60: 2-phenylethyl pivalate }\end{array}$ & $\begin{array}{l}\text { 12\%: palmitic acid } \\
\text { 27\%: pivalic acid } \\
\text { 41\%: 2-phenylethyl palmitate } \\
\text { 20\%: 2-phenylethyl pivalate }\end{array}$ \\
\hline 9 & $\begin{array}{l}\text { Acetic- } \\
\text { Palmitic }\end{array}$ & $\begin{array}{l}\text { 2-Phenyl- } \\
\text { ethanol }\end{array}$ & $\begin{array}{l}\text { 1700: acid } \\
\text { 1739:ester }\end{array}$ & $\begin{array}{l}\text { 179.03: palmitic acid } \\
\text { 178.12: acetic acid } \\
\text { 173.93: 2-phenylethyl palmitate } \\
\text { 171.16: 2-phenylethyl acetate }\end{array}$ & $\begin{array}{l}\text { 12.84\%: palmitic acid } \\
\text { 1.7\%: acetic acid } \\
42.73 \%: 2 \text {-phenylethyl palmitate } \\
42.73 \%: 2 \text {-phenylethyl acetate }\end{array}$ \\
\hline
\end{tabular}

${ }^{a} \mathrm{NMR}$ samples (entry: 1, 2, 3, 8 and 9) realized in $\mathrm{CDCl}_{3}$ and NMR samples (entry: 4, 5, 6 and 7) realized in the (CDCl $/ \mathrm{CDMO}^{2}$ mixture.

${ }^{\mathrm{b}}$ Composition of crude mixture determined by ${ }^{1} \mathrm{H}$ NMR.

${ }^{\mathrm{c}}$ The molar ratio (anhydride/alcohol) is (1:4).

The action of crude mixed anhydrides on primary (2-phenylethanol and benzyl alcohol) or secondary (2butanol)alcohols proceeded in hexane under reflux, in the presence of ion-exchange resin (Amberlyst-15) as heterogeneous catalyst $\mathrm{t}^{15)}$. The reaction mixture, consisted of the two acids and two esters, was so complex as shown in Scheme $2^{15,16)}$.

The esterification reaction was performed with crude mixed aromatic palmitic anhydrides (benzoic palmitic, 4-chlorobenzoic palmitic) and mixed aliphatic palmitic anhydrides (palmitic pivalic and acetic palmitic) on alcohols (2-phenylethanol, alcohol benzyl and 2-butanol)with a molar ratio (anhydride/alcohol) 1:2 in the presence of $2 \mathrm{~g}$ of Amberlyst-15 resin (9.4 meq active sites $/ 1.310^{-3} \mathrm{~mol}$ of mixture crude anhydride). The structures of the products obtained at the end of reaction were determined by IR and $\left({ }^{1} \mathrm{H}\right.$ and $\left.{ }^{13} \mathrm{C}\right) \mathrm{NMR}$ analyses and the results are shown in Table 2.

Representative IR, ${ }^{13} \mathrm{C}$ NMR and ${ }^{1} \mathrm{H}$ NMR spectra of the crude product, obtained by esterification of 2 phenhylethanol with 4-chlorobenzoic palmitic anhydride(Table 3 entry 2), were taken as representative examples and included respectively in Figs. 1, 2 and 3.

The IR spectra showed that all crude products were 
Table 3 Effect of Amberlyst-15 catalyst amount.

\begin{tabular}{|c|c|c|c|c|c|c|}
\hline Entry $^{a}$ & Alcohol & $\begin{array}{l}\text { Catalyst } \\
\text { amount }(\mathrm{g})\end{array}$ & $\begin{array}{c}\mathrm{IR} \\
\left(\mathrm{C}=\mathrm{O}, \mathrm{cm}^{-1}\right)\end{array}$ & ${ }^{13} \mathrm{C}$ RMN $(\mathrm{C}=\mathrm{O}, \mathrm{ppm})$ & Crude mixture composition ${ }^{b}$ & $\begin{array}{l}\text { Yield of } \\
\text { ester }(\%)\end{array}$ \\
\hline 1 & $\begin{array}{l}\text { 2-Phenyl- } \\
\text { ethanol }\end{array}$ & 2 & $\begin{array}{l}\text { 1697: acid } \\
\text { 1729: ester }\end{array}$ & $\begin{array}{l}\text { 166.94: 4-Cl-benzoic acid } \\
\text { 173.13: 2-phenylethyl palmitate }\end{array}$ & $\begin{array}{l}\text { 45\%: 4-Cl-benzoic acid } \\
52 \%: 2 \text {-phenylethyl palmitate } \\
\text { 3\%: 2-phenylethyl 4-Cl-benzoate }\end{array}$ & 92.69 \\
\hline 2 & & 0.5 & $\begin{array}{l}\text { 1697: acid } \\
\text { 1729: ester }\end{array}$ & $\begin{array}{l}\text { 166.95: 4-Cl-benzoic acid } \\
\text { 173.11: 2-phenylethyl palmitate }\end{array}$ & $\begin{array}{l}\text { 43\%: 4-Cl-benzoic acid } \\
\text { 53\%: 2-phenylethyl palmitate } \\
\text { 3\%: 2-phenylethyl 4-Cl-benzoate }\end{array}$ & 94.47 \\
\hline 3 & & 0.25 & $\begin{array}{l}\text { 1697: acid } \\
\text { 1729: ester }\end{array}$ & $\begin{array}{l}\text { 166.95: 4-Cl-benzoic acid } \\
\text { 173.11: 2-phenylethyl palmitate }\end{array}$ & $\begin{array}{l}\text { 44\%: 4-Cl-benzoic acid } \\
52 \%: 2 \text {-phenylethyl palmitate } \\
\text { 4\%: 2-phenylethyl 4-Cl-benzoate }\end{array}$ & 92.69 \\
\hline 4 & Benzyl & 2 & $\begin{array}{l}\text { 1695: acid } \\
\text { 1733: ester }\end{array}$ & $\begin{array}{l}\text { 175.84: palmitic acid } \\
\text { 167.38: 4-Cl-benzoic acid } \\
\text { 173.43: benzyl palmitate }\end{array}$ & $\begin{array}{l}46 \% \text { : palmitic acid } \\
40 \% \text { : 4-Cl-benzoic acid } \\
\text { 14\%: benzyl palmitate }\end{array}$ & 30.23 \\
\hline 5 & & 0.5 & $\begin{array}{l}\text { 1695: acid } \\
\text { 1733: ester }\end{array}$ & $\begin{array}{l}\text { 174.44: palmitic acid } \\
\text { 166.23: 4-Cl-benzoic acid } \\
\text { 172.33: benzyl palmitate }\end{array}$ & $\begin{array}{l}25 \% \text { : palmitic acid } \\
43 \% \text { : } 4-C l-b e n z o i c ~ a c i d \\
32 \% \text { : benzyl palmitate }\end{array}$ & 69.11 \\
\hline 6 & & 0.25 & $\begin{array}{l}\text { 1695: acid } \\
\text { 1733: ester }\end{array}$ & $\begin{array}{l}\text { 166.77: 4-Cl-benzoic acid } \\
\text { 172.86: benzyl palmitate }\end{array}$ & $\begin{array}{l}\text { 46\%: 4-Cl-benzoic acid } \\
\text { 51\%: benzyl palmitate } \\
\text { 3\%: benzyl 4-Cl-benzoate }\end{array}$ & 90.90 \\
\hline 7 & 2-Butanol & 2 & $\begin{array}{l}\text { 1689: acid } \\
\text { 1733: ester }\end{array}$ & $\begin{array}{l}\text { 175.45: palmitic acid } \\
\text { 167.04: 4-Cl-benzoic acid } \\
\text { 173.03: 2-butyl palmitate }\end{array}$ & $\begin{array}{l}45 \% \text { : palmitic acid } \\
41 \% \text { : 4-Cl-benzoic acid } \\
\text { 14\%: 2-butyl palmitate }\end{array}$ & 30.23 \\
\hline 8 & & 0.5 & $\begin{array}{l}\text { 1689: acid } \\
\text { 1732: ester }\end{array}$ & $\begin{array}{l}\text { 174.89: palmitic acid } \\
\text { 166.85: 4-Cl-benzoic acid } \\
\text { 172.68: 2-butyl palmitate }\end{array}$ & $\begin{array}{l}\text { 26\%: palmitic acid } \\
\text { 40\%: 4-Cl-benzoic acid } \\
\text { 34\%: 2-butyl palmitate }\end{array}$ & 73.43 \\
\hline 9 & & 0.25 & $\begin{array}{l}\text { 1689: acid } \\
\text { 1732: ester }\end{array}$ & $\begin{array}{l}\text { 175.20: palmitic acid } \\
\text { 166.86: 4-Cl-benzoic acid } \\
\text { 173.85: 2-butyl palmitate }\end{array}$ & $\begin{array}{l}12 \%: \text { palmitic acid } \\
45 \%: 4 \text {-Cl-benzoic acid } \\
42 \%: 2 \text {-butyl palmitate } \\
1 \%: 2 \text {-butyl 4-Cl-benzoate }\end{array}$ & 90.71 \\
\hline
\end{tabular}

${ }^{\mathrm{a}} \mathrm{NMR}$ samples realized in the $\left(\mathrm{CDCl}_{3} / \mathrm{DMSO}\right)$ mixture.

${ }^{\mathrm{b}}$ Composition of crude mixture determined by ${ }^{1} \mathrm{H}$ NMR.

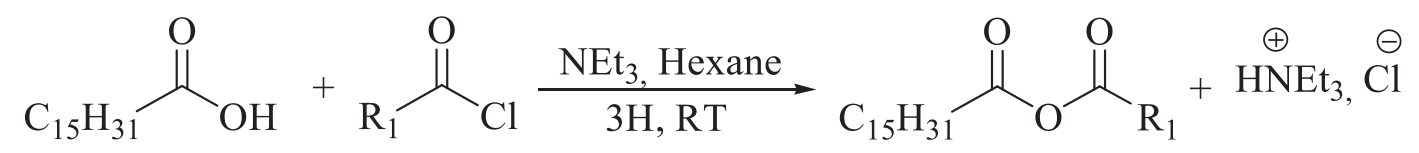

Scheme 1 Synthesis of mixed carboxylic-palmitic anhydride.

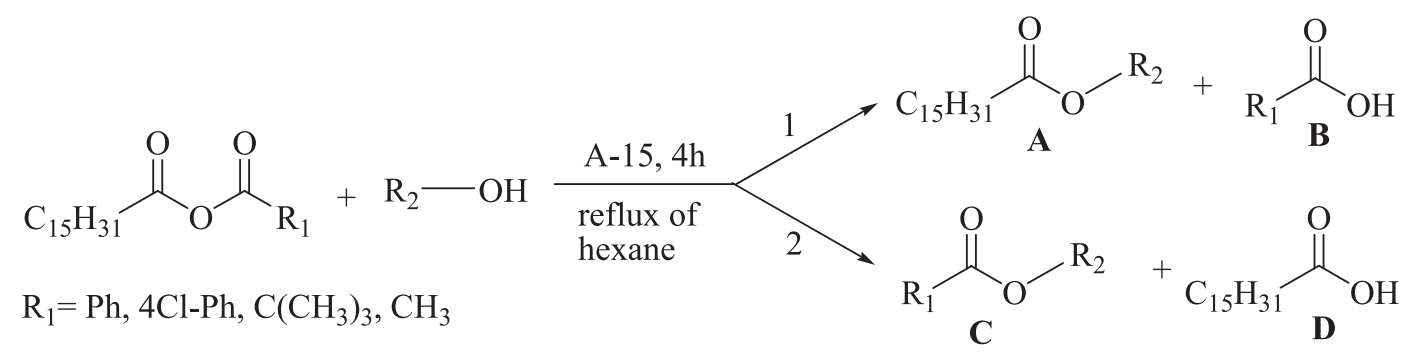

Scheme 2 Esterification reaction of mixed anhydride with alcohol. 


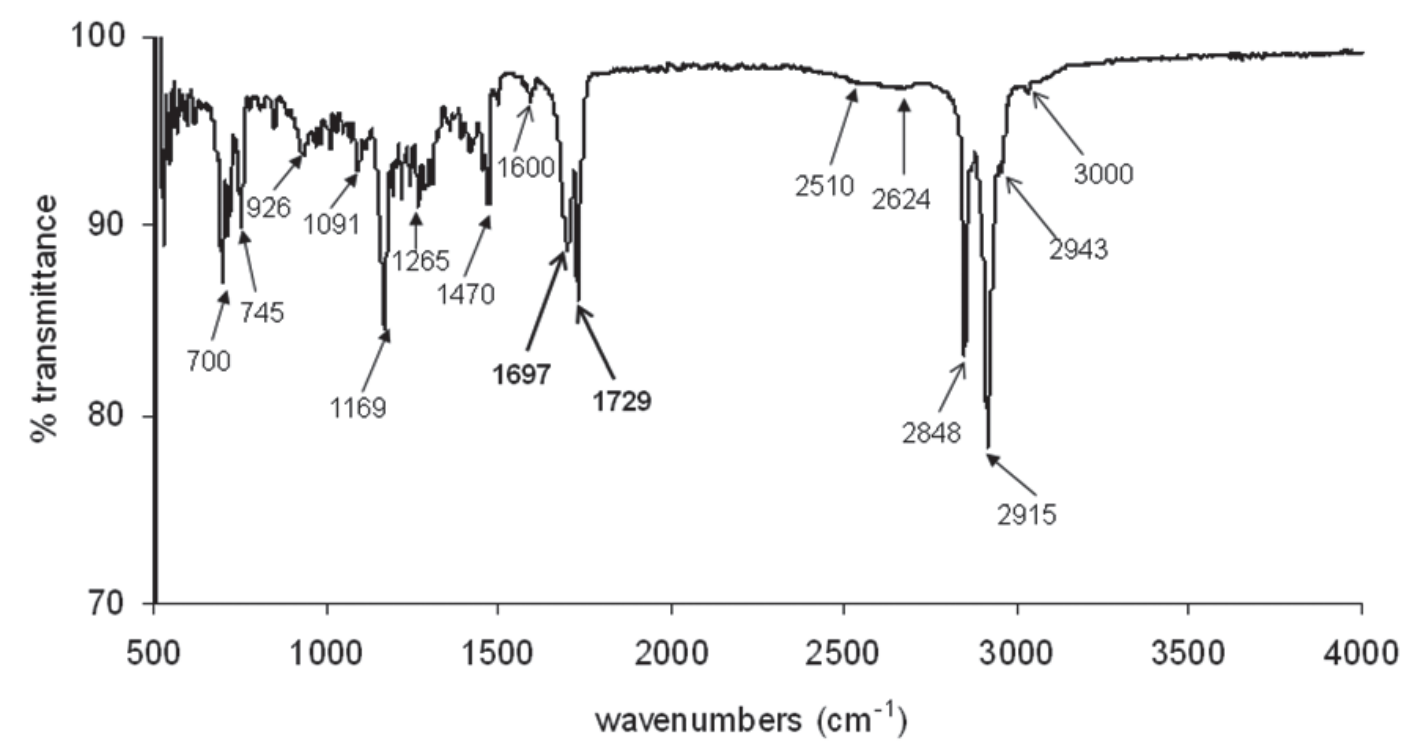

Fig. 1 FT-IR spectrum of the crude product obtained by esterification of 2 phenhyl- ethanol with 4-chlorobenzoic-palmitic anhydride (Table 3 entry 2).
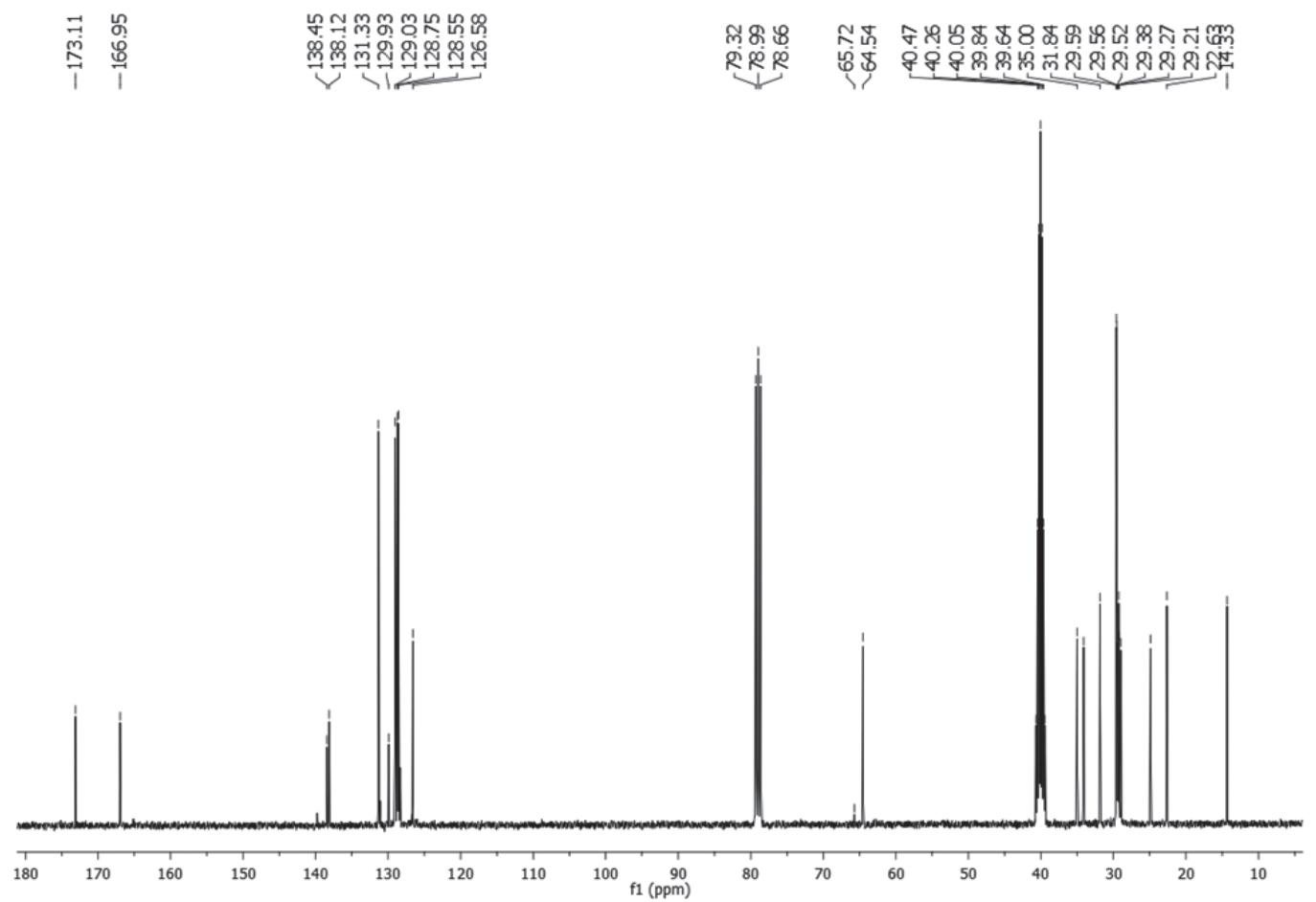

Fig. $2{ }^{13} \mathrm{C}$ NMR spectrum of the crude product obtained by esterification of 2 phenhyl- ethanol with 4-chlorobenzoicpalmitic anhydride (Table 3 entry 2).

mixture of esters and acids. The FT-IR spectrum showed an intense carbonyl stretch at $1700 \mathrm{~cm}^{-1}$ that corresponded to carboxylic acid. The presence of broad O-H band of acid in IR spectrum was observed between 2500 and 3000 $\mathrm{cm}^{-1}$. A stretch peak was observed at $(1733-1739) \mathrm{cm}^{-1}$ corresponding to ester carbonyl group and C-O band centred on $(1150,1280) \mathrm{cm}^{-1}$. Aliphatic $\mathrm{C}-\mathrm{H}$ band was observed at $(2880-2970) \mathrm{cm}^{-1}$.
The analysis by ${ }^{13} \mathrm{C}$ NMR confirmed these remarks. Some ${ }^{13} \mathrm{C}$ NMR spectra showed indeed, 4 peaks relating to a carbonyl $(\mathrm{C}=\mathrm{O})$ in the region $(166-180 \mathrm{ppm})$, reflecting the presence of mixture of two types of ester and two types of acid (entry $1,8,9)$. Other ${ }^{13} \mathrm{C}$ NMR spectra showed 2 or 3 peaks relating to a carbonyl $(\mathrm{C}=\mathrm{O})$ reflecting the presence of mixture of a single type of ester and two types of acid (entry 2, 3, 5, 6, 7) or the presence of mixture of a single 


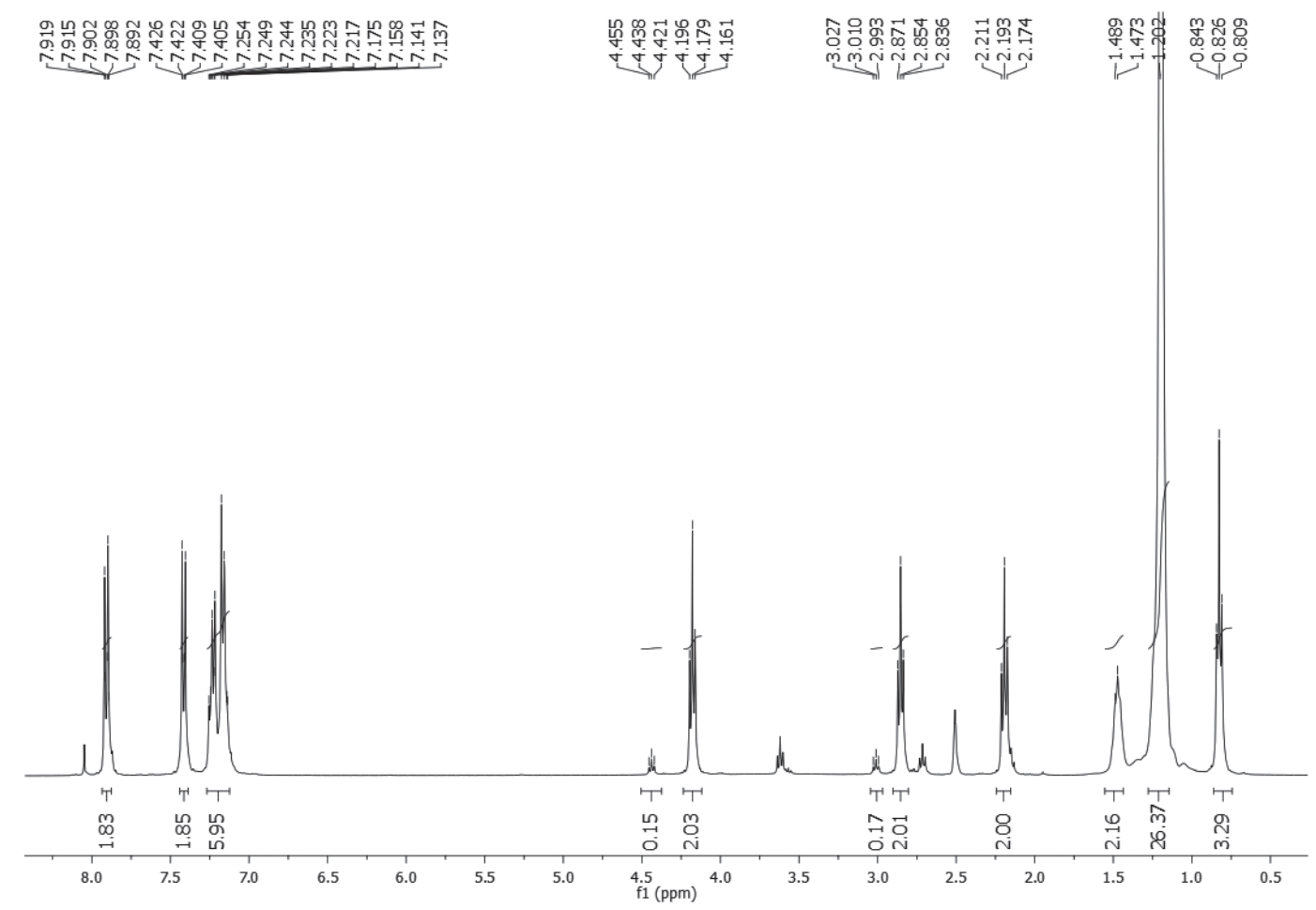

Fig. $3 \quad{ }^{1} \mathrm{H}$ NMR spectrum of the crude product obtained by esterification of 2 phenhyl- ethanol with 4-chlorobenzoicpalmitic anhydride (Table 3 entry 2 ).

type of ester and single type of acid (entry 4$)$.

The ${ }^{1} \mathrm{H}$ NMR analysis confirmed the presence of mixture of esters and acids in most of crude reaction products. The best yields of 2-phenylethyl palmitate were obtained in the case of mixed aromatic palmitic anhydrides (entry 1 : $49.70 \%$ and entry $4: 52 \%)$. The existence of an electron withdrawing group $(\mathrm{Cl})$ on aromatic ring of mixed anhydride promotes the formation reaction(1) of palmitic acid ester (entry 4: 52\%). Similar results were emphasized in the literature. They show that electron-withdrawing groups $(\mathrm{Cl}$, $\mathrm{F}, \mathrm{NO}_{2}$ ) increase the reactivity of substituted benzoic anhydrides and promote the formation of aliphatic esters ${ }^{15,17-19)}$. In addition, the formation rate of benzoic ester was much slower than that of aliphatic acid ester when we used the mixed anhydrides as reagents of esterification ${ }^{15,16,19)}$. Indeed, the aromatic acid esters were obtained in a low yield in the case of esterification by the mixed aromatic palmitic anhydrides (entry 1: 14.74\% and entry 4: 3\%). These results indicate that 4-chlorobenzoic palmitic anhydride was more reactive and more selective than benzoic palmitic anhydride in the case of esterification of primary alcohol (2-phenylethanol).

Mixed Aliphatic palmitic anhydrides were less reactive and less selective than their mixed aromatic palmitic anhydrides. The 2-phenylethyl palmitate was obtained with a less yield in the case of palmitic pivalic and acetic palmitic anhydrides (entry 8: $41 \%$ and entry 9: $42.73 \%$ ). we note that the esterification with these anhydrides promotes the reaction 2 (Scheme 2) and leads to the formation of undesirable ester $\mathrm{C}$ with important yield (entry 8: $20 \%$ and entry 9: $42.73 \%$ ).

4-chlorobenzoic palmitic anhydride remained selective in the esterification reaction of benzyl alcohol giving only benzyl palmitate but with a yield (entry 5: 16\%) lower than that recorded in the case of esterification of 2-phenylethanol. Benzoic palmitic anhydride was selective but less reactive than 4-chlorobenzoic palmitic anhydride in the case of esterification by benzyl alcohol (entry 2: 8\%).

Mixed Aromatic palmitic anhydrides were selective in the case of esterification by the secondary alcohol (2butanol) but less reactive. As example the 2-butyl palmitate esterified with 4-chlorobenzoic palmitic anhydride was obtained with a $14 \%$ yield (entry 6 ) and that when anhydride and alcohol were employed in stoichiometric amounts. Improved yield of 2-butyl palmitate (entry 7: 31\%) was observed when increasing the molar ratio (anhydride/alcohol) from 1:2 to 1:4. Benzoic palmitic anhydride was selective but less reactive than 4-chlorobenzoic palmitic anhydride in the esterification of 2-bantanol (entry 3: 10\%).

The molar compositions of crude products, obtained from ${ }^{1} \mathrm{H}$ NMR spectra, showed that the amount of palmitic acid ester in the reaction mixtures depended on the nature of alcohol and mixed anhydride used in esterification reaction. To improve the yield of esterification of primary and secondary alcohols, we have varied the molar ratio (anhydride/alcohol) and the amount of catalyst while keeping 
Table 4 Theoretical composition in the crude mixture of esterification reaction.

\begin{tabular}{ll}
\hline \multicolumn{1}{c}{ Crude anhydride composition } & $\begin{array}{c}\text { Theoretical composition of the crude } \\
\text { mixture: Esterification by palmitic group }\end{array}$ \\
\hline 73\%: 4-Cl-benzoic palmitic anhydride & $9.8 \%$ : palmitic acid \\
19.6\%: palmitic anhydride & $40.2 \%: 4-C l-$ benzoic acid \\
7.4\%: 4-Cl-benzoic anhydride & $46.3 \%$ : palmitic acid ester \\
& $3.7 \%$ : 4-Cl-benzoic acid ester \\
\hline
\end{tabular}

constant the other experimental conditions such as solvent, time reaction and temperature. This study was performed with 4-chlorobenzoic palmitic anhydride as most selective and responsive in the esterification of tested primary and secondary alcohols.

\subsubsection{Effect of Amberlyst-15 catalyst amount}

To study the effect of resin amount on the yield of palmitic acid esters, the esterification of alcohols (2-phenylethanol, benzyl alcohol and 2-butanol) with 4-chlorobenzoic palmitic anhydride was carried out with a molar ratio(anhydride/alcohol) equal to $1: 2$ and in the presence of $2 \mathrm{~g}, 0.5$ $\mathrm{g}$ and $0.25 \mathrm{~g}$ of Amberlyst-15 resin corresponding respectively to the ratios 4, 1 and 0.5 (equivalent of active sites/ equivalent of alcohol). The structures of products obtained at the end of reaction were determined by IR and $\left({ }^{1} \mathrm{H}\right.$ and ${ }^{13} \mathrm{C}$ ) NMR analysis (Table 3).

The yields of palmitic acid esters were calculated by the ratio between the experimental molar percentage of these esters and their theoretical molar percentage directly related to the starting anhydride mixture composition. The theoretical molar compositions were calculated assuming that 4-chlorobenzoic-palmitic anhydride reacted only by its palmitic group, the results of this calculation are shown in Table 4.

It was noted a decrease in the resin amount accompanied by a clear increase in the molar percentage of palmitic acid esters of benzyl alcohol and 2-butanol (entry 6: 90.90\% and entry 9: $90.71 \%$ ).

We note that the selectivity of esterification reaction was not affected by the variation of resin amount because we obtain in all cases a reaction mixture consisting by palmitic acid ester. The resin amount did not affect the composition of reaction mixture in the case of 2-phenylethanol but had a remarkable effect in case of the two other alcohols.

These results are in good agreement with those of literature who show that the presence of wide excess of active sites (with regard to the reactants) can have an inhibitory effect on the rate of esterification reaction. It was shown that the reaction rate of esterification of free fatty acids in olive-pomace oil with ethanol in the presence of macroporous ion exchange resin type SPC118 was maximal for a ratio (active sites/free fatty acids) equal to $1^{20,21)}$. We have proven in a previous work realized in our laboratory that when the ratio (active sites/alcohol) was equal or less to 1 , the yield was better than if the ratio was greater ${ }^{21)}$. This was probably due to the presence of excess in active sites which caused a decrease in probability of meeting of reactants in the same active site so the yield in product of reaction decreased too ${ }^{21,22)}$.

3.1.2 Effect of molar ratio (anhydride/alcohol)

We have studied the effect of molar ratio (anhydride/ alcohol) on the yield of palmitic acid esters. Esterification was performed by 2-phenylethanol or benzyl as primary alcohols and by 2-butanol as secondary alcohol, with crude mixed 4-Cl-benzoic-palmitic anhydride. The reactions were performed in the presence of $0.5 \mathrm{~g}$ of Amberlyst-15 resin. The molar ratios (anhydride/alcohol) were fixed to 1:1, 1:2 and 1:4, corresponding respectively to the reports (equivalent of active sites/equivalent of alcohol) of 2, 1 and 0.5. The structures of the obtained products were determined by IR and $\left({ }^{1} \mathrm{H}\right.$ and $\left.{ }^{13} \mathrm{C}\right) \mathrm{NMR}$ analysis and the yields of palmitic acid esters were calculated by the ratio between the experimental molar percentage of these esters and their theoretical molar percentage (Table 5).

We note that the selectivity of esterification reaction was not affected by the variation of molar ratio (anhydride/ alcohol) because we have obtained in all cases a reaction mixture consisting by the palmitic acid ester. It should be noted that any increase in the molar ratio (anhydride/ alcohol)was accompanied by an increase in the molar percentage of palmitic acid ester for the three alcohols. Palmitic acid was totally esterified from a molar ratio (anhydride/alcohol) 1:2 in the case of 2-phenylethanol. Palmitate 2-phenylethyl was obtained with a yield of $94.47 \%$ (entry 2 ). In the case of esterification of the two other alcohols, it was necessary to increase the molar ratio (anhydride/ alcohol) beyond 1:2 to improve the yield in palmitic acid esters. For a molar ratio (anhydride/alcohol) equal to 1:4, with benzyl alcohol and 2-butanol, a yield of $90 \%$ was reached. This improvement was attributed mainly to the displacement of chemical equilibrium of esterification reaction when we increased the concentration of one of the two reactants and also to the decrease of ratio (equivalent of active sites/equivalent of alcohol) which passed from 2 to 0.5 .

It was clear, in light of these results that mixed 4-chlorobenzoic palmitic anhydride had good reactivity and high selectivity for esterification of primary and secondary alcohols. Experimental conditions used in the initial moment were essentially related to the amount of ion exchange 
Table 5 Effect of molar ratio (anhydride/alcohol).

\begin{tabular}{|c|c|c|c|c|c|c|}
\hline Entry $^{\mathrm{a}}$ & Alcohol & $\begin{array}{c}\text { Molar } \\
\text { rapport } \\
\text { (anhydride/ } \\
\text { alcohol) }\end{array}$ & $\begin{array}{c}\mathrm{IR} \\
\left(\mathrm{C}=\mathrm{O}, \mathrm{cm}^{-1}\right)\end{array}$ & ${ }^{13} \mathrm{C} \mathrm{RMN}(\mathrm{C}=\mathrm{O}, \mathrm{ppm})$ & Crude mixture composition ${ }^{\mathrm{b}}$ & $\begin{array}{l}\text { Yield of } \\
\text { ester (\%) }\end{array}$ \\
\hline 1 & $\begin{array}{l}\text { 2-Phenyl- } \\
\text { ethanol }\end{array}$ & $1: 1$ & $\begin{array}{l}\text { 1697: acid } \\
\text { 1729: ester }\end{array}$ & $\begin{array}{l}\text { 174.87: palmitic acid } \\
\text { 166.70: 4-Cl-benzoic acid } \\
\text { 172.87: 2-phenylethyl palmitate }\end{array}$ & 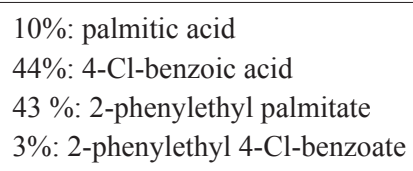 & 92.87 \\
\hline 2 & & $1: 2$ & $\begin{array}{l}\text { 1697: acid } \\
\text { 1729: ester }\end{array}$ & $\begin{array}{l}\text { 166.95: 4-Cl-benzoic acid } \\
\text { 173.11: 2-phenylethyl palmitate }\end{array}$ & $\begin{array}{l}\text { 43\%: 4-Cl-benzoic acid } \\
53 \%: 2 \text {-phenylethyl palmitate } \\
\text { 3\%: 2-phenylethyl 4-Cl-benzoate }\end{array}$ & 94.47 \\
\hline 3 & Benzyl & $1: 1$ & $\begin{array}{l}\text { 1695: acid } \\
\text { 1733: ester }\end{array}$ & $\begin{array}{l}\text { 174.83: palmitic acid } \\
\text { 166.67: 4-Cl-benzoic acid } \\
\text { 172.73: benzyl palmitate }\end{array}$ & $\begin{array}{l}42 \% \text { : palmitic acid } \\
40 \% \text { : } 4-C l-b e n z o i c ~ a c i d \\
18 \% \text { : benzyl palmitate }\end{array}$ & 38.87 \\
\hline 4 & & $1: 2$ & $\begin{array}{l}\text { 1695: acid } \\
\text { 1733: ester }\end{array}$ & $\begin{array}{l}\text { 174.44: palmitic acid } \\
\text { 166.23: 4-Cl-benzoic acid } \\
\text { 173.33: benzyl palmitate }\end{array}$ & $\begin{array}{l}\text { 25\%: palmitic acid } \\
43 \% \text { : } 4-C l-b e n z o i c ~ a c i d \\
32 \% \text { : benzyl palmitate }\end{array}$ & 69.11 \\
\hline 5 & & $1: 4$ & $\begin{array}{l}\text { 1695: acid } \\
\text { 1733: ester }\end{array}$ & $\begin{array}{l}\text { 166.91: 4-Cl-benzoic acid } \\
\text { 173.02: benzyl palmitate }\end{array}$ & $\begin{array}{l}\text { 47\%: 4-Cl-benzoic acid } \\
\text { 50\%: benzyl palmitate } \\
\text { 3\%: benzyl 4-Cl-benzoate }\end{array}$ & 89.12 \\
\hline 6 & 2-Butanol & $1: 1$ & $\begin{array}{l}\text { 1686: acid } \\
\text { 1733: ester }\end{array}$ & $\begin{array}{l}\text { 175.08: palmitic acid } \\
\text { 166.7: 4-Cl-benzoic acid } \\
\text { 172.77: 2-butyl palmitate }\end{array}$ & $\begin{array}{l}\text { 30\%: palmitic acid } \\
\text { 50\%: 4-Cl-benzoic acid } \\
\text { 20\%: 2-butyl palmitate }\end{array}$ & 43.19 \\
\hline 7 & & $1: 2$ & $\begin{array}{l}\text { 1689: acid } \\
\text { 1732: ester }\end{array}$ & $\begin{array}{l}\text { 174.89: palmitic acid } \\
\text { 166.85: 4-Cl-benzoic acid } \\
\text { 172.68: 2-butyl palmitate }\end{array}$ & $\begin{array}{l}\text { 26\%: palmitic acid } \\
\text { 40\%: 4-Cl-benzoic acid } \\
\text { 34\%: 2-butyl palmitate }\end{array}$ & 73.43 \\
\hline 8 & & $1: 4$ & $\begin{array}{l}\text { 1689: acid } \\
\text { 1732: ester }\end{array}$ & $\begin{array}{l}\text { 175.24: palmitic acid } \\
\text { 167: 4-Cl-benzoic acid } \\
\text { 172.95: 2-butyl palmitate }\end{array}$ & $\begin{array}{l}\text { 13\%: palmitic acid } \\
\text { 42\%: 4-Cl-benzoic acid } \\
\text { 43\%: 2-butyl palmitate } \\
\text { 2\%: 2-butyl 4-Cl-benzoate }\end{array}$ & 92.87 \\
\hline
\end{tabular}

${ }^{a} \mathrm{NMR}$ samples realized in the $\left(\mathrm{CDCl}_{3} / \mathrm{DMSO}\right)$ mixture.

${ }^{\mathrm{b}}$ Composition of crude mixture determined by ${ }^{1} \mathrm{H}$ NMR.

resin catalyst (Amberlyst-15) and to the molar ratios of reactants. Excellent yields of esterification of primary and secondary alcohols were reached when a molar ratio (equivalent of active sites/equivalent of alcohol) was equal or less to 1 and molar ratio of reactants (anhydride/alcohol) equal or greater than 1:2.

\subsection{Esterification of tertiary alcohols with crude mixed anhydrides}

Preliminary tests of esterification of tertiary alcohols (2-methyl-2-propanol and salicylic acid) were realized with crude mixed anhydrides. The molar ratio of reactants (anhydride/alcohol) was fixed to 1:2 and the quantity of Amberlyst-15 resin to $0.5 \mathrm{~g}$ (ratio (equivalent active sites/ equivalent alcohol) equal to 1). The reaction with 2-methyl2-propanol was carried out in hexane and that of salicylic acid, non soluble in hexane, was carried out in dichloromethane. The structures of products obtained at the end of reaction were determined by $\mathrm{IR},{ }^{13} \mathrm{C} \mathrm{NMR}$ and ${ }^{1} \mathrm{H}$ NMR analysis (Table 6).

We note that all mixtures obtained at the end of reactions did not contain any traces of ester and anhydrides used as reactants were completely converted to their corresponding acids. We assume that this behavior is due to the sterical hindrance that impedes the access towards the reaction center, or in some cases the access is limited, that makes the reaction rate very slow compared with normalchain alcohols ${ }^{23)}$.

\section{Conclusion}

In the present work, we have investigated the reactivity of some mixed anhydrides of palmitic acid in the esterification reaction of primary, secondary and tertiary alcohols and in the presence of resin Amberlyst-15 as heterogeneous catalyst. We have optimized the conditions for maximum yields of esterification by varying different reac- 
Esterification of Mixed Carboxylic-fatty Anhydrides Using Amberlyst-15

Table 6 Esterification of tertiary alcohols with crude mixed anhydrides.

\begin{tabular}{|c|c|c|c|c|c|}
\hline Entry $^{\mathrm{a}}$ & $\begin{array}{l}\text { Crude mixed } \\
\text { anhydride }\end{array}$ & Alcohol & $\begin{array}{c}\mathrm{IR} \\
\left(\mathrm{C}=\mathrm{O}, \mathrm{cm}^{-1}\right)\end{array}$ & ${ }^{13} \mathrm{C} \mathrm{RMN}(\mathrm{C}=\mathrm{O}, \mathrm{ppm})$ & Crude mixture composition ${ }^{\mathrm{b}}$ \\
\hline 1 & $\begin{array}{l}\text { Benzoic- } \\
\text { Palmitic }\end{array}$ & $\begin{array}{l}\text { 2-Methyl-2- } \\
\text { propanol }\end{array}$ & 1684: acid & $\begin{array}{l}\text { 180.74: palmitic acid } \\
\text { 172.4: benzoic acid }\end{array}$ & $\begin{array}{l}\text { 51\%: palmitic acid } \\
\text { 49\%: benzoic acid }\end{array}$ \\
\hline 2 & & Salicylic acid & 1682: acid & $\begin{array}{l}\text { 181.05: palmitic acid } \\
\text { 172.57: benzoic acid } \\
\text { 175.37: salicylic acid }\end{array}$ & $\begin{array}{l}\text { 25\%: palmitic acid } \\
25 \% \text { : benzoic acid } \\
50 \% \text { : salicylic acid }\end{array}$ \\
\hline 3 & $\begin{array}{l}\text { 4-Cl-benzoic- } \\
\text { Palmitic }\end{array}$ & $\begin{array}{l}\text { 2-Methyl-2- } \\
\text { propanol }\end{array}$ & 1686: acid & $\begin{array}{l}\text { 174.91: palmitic acid } \\
\text { 166.92: 4-Cl-benzoic acid }\end{array}$ & $\begin{array}{l}\text { 60\%: palmitic acid } \\
40 \% \text { : 4-Cl-benzoic acid }\end{array}$ \\
\hline 4 & & Salicylic acid & 1686: acid & $\begin{array}{l}\text { 175.02: palmitic acid } \\
\text { 166.90: 4-Cl-benzoic acid } \\
\text { 172.52: salicylic acid }\end{array}$ & $\begin{array}{l}\text { 25\%: palmitic acid } \\
\text { 25\%: 4-Cl-benzoic acid } \\
50 \% \text { : salicylic acid }\end{array}$ \\
\hline 5 & $\begin{array}{l}\text { Palmitic- } \\
\text { Pivalic }\end{array}$ & $\begin{array}{l}\text { 2-Methyl-2- } \\
\text { propanol }\end{array}$ & 1697: acid & $\begin{array}{l}\text { 180.60: palmitic acid } \\
\text { 185.66: pivalic acid }\end{array}$ & $\begin{array}{l}50 \%: \text { palmitic acid } \\
50 \% \text { : pivalic acid }\end{array}$ \\
\hline 6 & & Salicylic acid & 1695: acid & $\begin{array}{l}\text { 180: palmitic acid } \\
\text { 185.59: pivalic acid } \\
\text { 175: salicylic acid }\end{array}$ & $\begin{array}{l}25 \%: \text { palmitic acid } \\
25 \%: \text { pivalic acid } \\
50 \%: \text { salicylic acid }\end{array}$ \\
\hline 7 & $\begin{array}{l}\text { Acetic- } \\
\text { Palmitic }\end{array}$ & $\begin{array}{l}\text { 2-Methyl-2- } \\
\text { propanol }\end{array}$ & 1696: acid & $\begin{array}{l}\text { 180.16: palmitic acid } \\
\text { 178: acetic acid }\end{array}$ & $\begin{array}{l}80 \%: \text { palmitic acid } \\
\text { 20\%: acetic acid }\end{array}$ \\
\hline 8 & & Salicylic acid & 1695: acid & $\begin{array}{l}\text { 180: palmitic acid } \\
\text { 178: acetic acid } \\
\text { 175: salicylic acid }\end{array}$ & $\begin{array}{l}\text { 33\%: palmitic acid } \\
\text { 17\%: acetic acid } \\
\text { 50\%: salicylic acid }\end{array}$ \\
\hline
\end{tabular}

${ }^{a}$ NMR samples (entry: 1, 2, 5, 6, 7 and 8) realized in $\mathrm{CDCl}_{3}$ and $\mathrm{NMR}$ samples (entry: 3 and 4) realized in the $\left(\mathrm{CDCl}_{3} /\right.$ DMSO) mixture.

${ }^{\mathrm{b}}$ Composition of crude mixture determined by ${ }^{1} \mathrm{H}$ NMR.

tion parameters such as molar ratio (anhydride/alcohol), effect of catalyst amount and type of alcohol.

Among tested anhydrides we quote mainly 4-chlorobenzoic palmitic anhydride because it was both reactive and selective for the preparation of palmitic acid ester. Mixed aromatic palmitic anhydrides were selective in the case of esterification by secondary alcohol(2-butanol) but less reactive.

It was noted that a decrease in the resin amount was accompanied by a clear increase in the molar percentage of palmitic acid ester of benzyl alcohol and 2-butanol which means important yields of these esters. Any increase in the molar ratio of (anhydride/alcohol) was accompanied by an increase in the molar percentage of palmitic acid ester for the three alcohols (2-phenylethanol or benzyl alcohol as primary alcohols and by 2-butanol as a secondary alcohol). The palmitic acid was totally esterified from a molar ratio (anhydride/alcohol) 1:2 in the case of 2-phenylethanol. In the case of esterification of the two other alcohols, it was necessary to increase the molar ratio (anhydride/alcohol) beyond 1:2 to improve the yield of palmitic acid ester. This improvement was attributed mainly to the displacement of chemical of esterification reaction equilibrium when we increase the concentration of one of the two reactants and also to the decrease of ratio (equivalent of active sites/ equivalent of alcohol) which passed from 2 to 0.5 . The reaction between prepared mixed anhydrides with some tertiary alcohols did not contain traces of ester and the anhydrides used as reactants were completely converted to their corresponding acids.

Actually we are studying the synthesis of sugar esters by the esterification reaction of sugar with mixed carboxylicpalmitic anhydrides using resin Amberlyst-15 as heterogeneous acid catalyst. Sugar esters are nonionic surfactants. Their potential applications extend from human food to drugs formulation and biochemical studies. The most studied methods were the biotechnological ways using enzyme as a catalyser.

\section{References}

1) Sun, H.B.; Hua, R.; Yin, Y. $\mathrm{ZrOCl}_{2} \cdot 8 \mathrm{H}_{2} \mathrm{O}$ : An efficient, cheap and reusable catalyst for the esterification of acrylic acid and other carboxylic acids with equimolar amounts of alcohols. Molecules 11, 263-271 (2006).

2) Shiina, I.; Kubota, M.; Oshiumi, H.; Hashizume, M. An effective use of benzoic anhydride and its derivatives 


\section{Trabelsi, K. Essid and M. H. Frikha}

for the synthesis of carboxylic esters and lactones: a powerful and convenient mixed anhydride method promoted by basic catalysts. J. Org. Chem. 69, 18221830 (2004).

3) Chakraborti, A.K.; Shivani, S. Magnesium bistrifluoromethanesulfonimide as a new and efficient acylation catalyst. J. Org. Chem. 71, 5785-5788(2006).

4) Firouzabadi, H.; Iranpoor, N.; Farahi, S. Solid trichlorotitanium (IV) trifluoromethanesulfonate $\mathrm{TiCl}_{3}$ (OTf) catalyzed efficient acylation of $-\mathrm{OH}$ and $-\mathrm{SH}$ : Direct esterification of alcohols with carboxylic acids and transesterification of alcohols with esters under neat conditions. J. Mol. Catal. A: Chem. 289, 61-68(2008).

5) Peydecastaing, J.; Vaca-Garcia, C.; Borredon, E. Consecutive reactions in an oleic acid and acetic anhydride reaction medium. Eur. J. Lipid Sci. Technol. 111, 723-729 (2009).

6) Hu, Y.L.; Zhao, X.E.; Lu, M. Efficient and convenient synthesis of symmetrical carboxylic anhydrides from carboxylic acids with sulfated zirconia by phase transfer catalysis. Bull. Chem. Soc. Ethiop. 25, 255-262 (2011).

7) Arni, P.C.; Gray. J.D.; Scougall, R.K. Chemical modification of wood. I. Use of trifluoroacetic anhydride in the esterification of wood by carboxylic acids. J. Appl. Chem. 11, 157-163 (1961).

8) Peydecastaing, J.; Vaca-Garcia, C.; Borredon, E. Linear anhydrides and carboxylic acids. Chromatographia 68, 685-688 (2008).

9) Chemat, F.; Poux, M.; Galema, S.A. Esterification of stearic acid by isomeric forms of butanol in a microwave oven under homogeneous and heterogeneous reaction conditions. J. Chem. Soc. Perkin. Trans. 2, 2371-2374(1997).

10) Brahmkhatri, V.; Patel, A. Esterification of lauric acid with butanol-1 over $\mathrm{H}_{3} \mathrm{PW}_{12} \mathrm{O}_{40}$ supported on MCM-41. Fuel 102, 72-77 (2012).

11) De Paiva, E.J.M.; Corazza, M.L.; Sierakowski, M.R.; Wärnå, J.; Murzin, D.Y.; Wypych, F.; Salmi, T. Influence of two different alcohols in the esterification of fatty acids over layered zinc stearate/palmitate. Bioresour. Technol. 193, 337-344(2015).

12) Zaidi, A.; Gainer, J.L; Carta, G.; Mrani, A.; Kadiri, T.; Belarbi, Y.; Mir, A. Esterification of fatty acids using nylon immobilized lipase in n-hexane: kinetic parameters and chain length effects. J. Biotechnol. 93, 209216(2002).
13) Peng, L.; Philippaerts, A.; Ke, X.; Van Noyen, J.; De Clippel, F.; Tendeloo, G.V.; Jacobs, P.A.; Sels, B.F. Preparation of sulfonated ordered mesoporous carbon and its use for the esterification of fatty acids. Catal. Today 150, 140-146 (2010).

14) Martínez, M.; Oliveros, R.; Aracil, J. Synthesis of biosurfactants: enzymatic esterification of diglycerol and oleic acid. 1. Kinetic modeling. Ind. Eng. Chem. Res. 50, 6609-6614 (2011).

15) Trabelsi, I.; Essid, K.; Frikha, M.H. Synthesis of mixed anhydrides of fatty acids: Stability and reactivity. Ind. Crop. Prod. 97, 552-557 (2017).

16) Peydecastaing, J.; Vaca-Garcia, C.; Borredon, E. Bi-acylation of cellulose: determining the relative reactivities of the acetyl and fatty-acyl moieties. Cellulose 18, 1015-1021 (2011).

17) Ishihara, K.; Kubota, M.; Kurihara, H.; Yamamoto, H. Scandium trifluoromethanesulfonate as an extremely active lewis acid catalyst in acylation of alcohols with acid anhydrides and mixed anhydrides. J. Org. Chem. 61, 4560-4567 (1996).

18) Shiina, I. An effective method for the synthesis of carboxylic esters and lactones using substituted benzoic anhydrides with Lewis acid catalysts. Tetrahedron 60, 1587-1599 (2004).

19) Shiina, I.; Kubota, M.; Oshiumi, H.; Hashizume, M. An effective use of benzoic anhydride and its derivatives for the synthesis of carboxylic esters and lactones: a powerful and convenient mixed anhydride method promoted by basic catalysts. J. Org. Chem. 69, 18221830 (2004).

20) Frikha, M.H.; Ben Zina, M.; Gabsi, S. Esterification of free fatty acids in olive oil with methanol or ethanol: inhibiting effect of alcohol. Bull. Soc. Chim. Fr. 133, 875-879 (1996).

21) Frikha, M.H.; Ben Zina, M.; Salem, M. Esterification kinetic equation of free fatty acids of degraded olive oil with ethanol at a temperature higher than that of azeotrope. Entropie 206, 48-54 (1997).

22) Bouguerra Neji, S.; Trabelsi, M.; Frikha, M.H. Esterification of fatty acid over Tunisian acid activated clay: kinetic study. J. Oleo Sci. 60, 293-299 (2011).

23) Stavarache, C.; Vinatoru, M.; Nishimura, R.; Maeda,Y. Fatty acids methyl esters from vegetable oil by means of ultrasonic energy. Ultrason. Sonochemi. 12, 367$72(2005)$. 